1993

\title{
Looking back on Goffman: The excavation continues
}

James J. Chriss

Cleveland State University

Follow this and additional works at: https://engagedscholarship.csuohio.edu/clsoc_crim_facpub

Part of the Criminology Commons

How does access to this work benefit you? Let us know!

Publisher's Statement

The final publication is available at Springer via http://link.springer.com/article/10.1007/

BF01323029

\section{Repository Citation}

Chriss, James J., "Looking back on Goffman: The excavation continues" (1993). Sociology \& Criminology Faculty Publications. 98.

https://engagedscholarship.csuohio.edu/clsoc_crim_facpub/98 


\title{
Looking back on Goffman: The excavation continues*
}

\author{
JAMES J. CHRISS
}

Department of Sociology, University of Pennsylvania, Philadelphia, PA 19104-6299

\section{Introduction: The examined life}

In a paper delivered to the University of Pennsylvania's Annenberg School for Communication Colloquium on 22 April 1991, Yves Winkin (1991:8) presented an outline of Erving Goffman's intellectual biography through an ingenious series of fifteen "snapshots." Snapshot 11 is related as follows:

Sometime in late 1959. Erving Goffman is up for tenure but he is persuaded he won't make it and he is ready to quit academia. In 1957, he was invited by Herbert Blumer to join the Department of Sociology of the University of California, Berkeley, to fit the niche of "social psychology" left vacant by the departure of T. Shibutani. On January 1, 1958, he was hired as "Visiting Assistant Professor" with a yearly salary of $\$ 6,840$.

In 1959, Presentation of Self in Everyday Life was an immediate seller, and his name becomes better and better known in the field. Yet the review committee, headed by Andreas Papandreou, then Chair of the Department of Economics, doesn't know what to decide. At least two of his colleagues are not very enthusiastic about hịs work (Bendix) and his personality (Blumer). The work is too soft, too literary and the personality is too abrupt, too difficult. But the letters (from Riesman, Hughes, Sarbin, Cottrell, Schneider) probably win the vote. Hughes speaks of "our Simmel." Goffman is promoted "Associate Professor Step 1" as of January, 1960 , with a salary of $\$ 7,920$. He teaches for a semester and then takes a 6 month leave without pay. He will stay in academia - but will avoid teaching when it can be avoided. ${ }^{1}$

\footnotetext{
* I would like to thank Yves Winkin, Dean MacCannell, Charles Bosk, and review editor Jim Ostrow for providing helpful comments on several earlier drafts of this essay.
} 
This snapshot helps to illustrate the precarious and highly contingent nature of the progression of human life, as well as the difficulties ethnographers and biographers encounter when attempting to treat a person's life holistically, as a linear and progressive chain of events (Wollheim, 1984).

When we look back then at Goffman's extremely successful thirty-year career, we can't help but marvel at the lucidity of his concepts and the seeming ease with which he was able to choose his words in forming his vision of the social world - however "soft," however "literary." But through the examination of Goffman's life and career we also come to realize something that Goffman himself understood perhaps better than anyone, and that is that the mental and physical competencies which we today so masterfully display and utilize in making our mark on the world were attained through an excruciating process of trial and error, of fits and starts which, especially in its early stages, was "negotiated in a cold sweat" (Goffman, 1971:248). Goffman's nearly dropping out of academia is certainly testimony to this.

There have been a number of eloquent tributes to and appraisals of Goffman and his work (e.g., Abrahams, 1984; Atkinson, 1989; Becker, 1984; Berger, 1973; Bock, 1988; Collins, 1986; Freidson, 1983; Hymes, 1984; Lofland, 1984; MacCannell, 1983; Marx, 1984; McGregor, 1986; Stein, 1991; Strong, 1983; R. Williams, 1983; and S. Williams, 1986), and many of these were of course published shortly after his death in 1982. Some would suggest, however, that any prolonged concern with a theorist qua human being beyond merely the sort of ritual attention occasioned by his or her passing is a misguided endeavor, a chatty sort of "theory-talk" (Turner, 1989; Lofland, 1984: 12-13) that contributes neither to a greater understanding of a particular theorist's work nor to knowledge cumulation more generally. However, if the recent "postmodern turn" in sociology teaches us anything at all, it is that there is no shame in striving for a greater contextualization of knowledge in our field, and this includes the overt task of matching a face and a biography to authors and their texts (Agger, 1989; Brown, 1990; Clough, 1992; Denzin, 1991; Gouldner, 1969; and Seidman, 1991, 1992).

\section{The excavation continues: Three recent works}

For a variety of good reasons, then, there has been an explosion of interest in Erving Goffman's oeuvre of late, and this "looking back" continues in three recent works. ${ }^{2}$

The collection of essays in Stephen Riggins' edited volume, Beyond Goffman: Studies on Communication, Institution, and Social Interaction 
(1990), offers a semiotic approach to understanding and extending Goffman's major concepts. Beyond Goffman (BG) is a large, 456 page volume containing 17 papers (in addition to the editor's introductory essay), all, of which are worth reading. ${ }^{3}$ Most of the papers were originally presented at an international conference held in December, 1987, at the Central Institute of Indian languages in Mysore, India. Editor Stephen Riggins has done a nice job of bringing together an interesting mix of Eastern and Western scholars from a variety of disciplines including sociology, linguistics, legal studies, communications, psychiatry, and anthropology.

The papers are grouped into two thematic sections over three parts. Part I is dedicated to theoretical issues in Goffman's sociology as well as investigations of his intellectual roots. The final two parts, entitled "Expanding the Scope," offer empirical and applied investigations which attempt to go "beyond Goffman." Part II focuses on institutions and forms of language. Part III is concerned with objects, events and communication.

Another edited volume, Paul Drew and Anthony Wootton's Erving Goffman: Exploring, the interaction order (1988), consists of nine essays whose organizing theme is the exploration of continuities in Goffman's work. As Drew and Wootton note in their introduction, the fact that there is no "Goffman tradition" in sociology or elsewhere begs the question, what did Goffman really leave behind for those attempting to continue his work? The contributors to this volume - Randall Collins, Anthony Giddens, Christian Heath, Adam Kendon, Stephen Levinson, Emanuel Schegloff, P.M. Strong, Robin Williams, and Stephen Levinson - offer insights into how we may indeed pick up Goffman's "golden shovel" (Hymes, 1984: 625). Because most of the papers arose from a 1986 conference held at the University of York on behalf of the British Sociological Association's Sociology of Language group, it is not surprising that much of the authors' attention is directed to Goffman's contribution to sociolinguistics and especially verbal forms of self-presentation. ${ }^{4}$

The final volume to be considered, Tom Burns's Erving Goffman (1992), is perhaps the most learned, and certainly the most comprehensive, analysis of Erving Goffman's work to date. Although the two edited collections offer a variety of approaches ostensibly organized around a particular theme, they simply cannot deliver the sort of unified understanding and analysis of Goffman's work which Burns's monograph provides. Over the course of 13 chapters and some 380 pages, Burns successfully develops and sustains a line of exegetical and critical inquiry touching on most of Goffman's major themes, including among others: social order versus the interaction order; "normalisation"; realms of being; out-of-frame activities; and the rhetoric of talk.

Rather than treating each work separately, I will discuss the three 
volumes thematically under the following four sections.

\section{Durkheim, Goffman and social order}

Many authors (e.g., Cheal, 1988b; Collins, 1975, 1980; Collins and Makowsky, 1972; Mitchell, 1978; and Miller 1982) have documented Goffman's penchant for employing Durkheimian imagery in the description of face-to-face behavior. In his "Theoretical continuities in Goffman's work" (Drew and Wootton, 1988), Randall Collins carries on this tradition by describing a recurrent feature of Goffman's writings, namely his emphasis on the sacred nature of the individual in modern society.

Dean MacCannell makes an important contribution to this topic in "The descent of the ego" (Riggins, 1990). Goffman followed Durkheim's attention to the sui generis reality of society by concentrating on the minutia of social life constituting the interaction order within which resides the vast array of norms and rituals guiding face-to-face interaction (also see Rawls, 1987). Like Durkheim, Goffman demonstrated, especially in Asylums, Stigma, and Relations in Public, a range of behaviors residing at the micro-level - such as face and eye work, civil inattention, body gloss, tie signs, deference and demeanor, embarrassment, and so forth - which was previously ceded to psychology and, in their deviant forms (e.g., alienation from interaction), to psychoanalysis (also see Travers, 1992: 228). As MacCannell explains, Goffman thereby provided an analytical model which helped drive "the sociological frame into the fine details of everyday life" (p. 21).

The "descent of the ego," then, was witnessed by both Durkheim and Goffman in terms of the mechanisms at work in modern Western society whereby the tendencies toward an unbridled egoistic individualism are continually rebuffed (Chriss, 1993). MacCannell successfully makes the case for such a Durkheim-Goffman link through a semiotic sociology which resists the temptation of explaining in solely positivistic terms why it is that in modern Western society, imbued as it is with a strong ethic of individualism, we nevertheless see persons orienting their actions toward a perceived moral universe and the accommodation of the other. Like Durkheim and many of the great students of society from Plato to Hobbes, from Kant to Parsons, Goffman was ultimately concerned with the question, how is social order possible (Berger, 1973: 356; Collins, 1980: 173)?

Burns recognizes the Durkheim-Goffman link as well, but carries the analysis even further by comparing and contrasting Durkheim's notion of social order with Goffman's interaction order. Durkheim's sui generis reality was society; Goffman's is the encounters between individuals, or the 
social act itself. The moral order which pervades society and sustains individual conduct constitutes a "social fact" in both Durkheim's and Goffman's eyes. But Burns (1992) notes also that for Durkheim this order was seen as durable and all-sustaining, whereas for Goffman "it was fragile, impermanent, full of unexpected holes, and in constant need of repair" (p. 26).

\subsection{The interaction order}

Just as many students of society have asked the question, "How is social order possible?," so too in Goffmanian terminology we may ask, "How is the interaction order possible?" Eric Schwimmer's "The anthropology of the interaction order" (Riggins, 1990) helps answer this. Schwimmer suggests that much of the anthropologic literature dealing with Indian society and southern Asia more generally is consonant with Goffman's thoroughly Westernized account of the interaction order, especially in terms of the "loose coupling" which he suggests exists between social structure and the actual social practices of agents. ${ }^{5}$ One of the overriding themes of the Riggins volume is in fact the cross-cultural relevance and applicability of Goffman's ideas. Although Goffman (e.g., 1953, 1959, 1961a, 1971, 1974,1981 a) went out of his way to alert his readers to the tenuousness and nongeneralizability of his findings - especially insofar as his ideas were forged solely within the cultural milieu of modern Western society contributors to this volume such as Schwimmer, Nirmala Srinivasan ("The cross-cultural relevance of Goffman's concept of individual agency"), R.S. Perinbanayagam ("How to do self with things"), Promode Misra ("The mediating role of objects in the functioning of social structure: A case study of kwai"), and T.K. Oommen ("Erving Goffman and the study of everyday protest") illustrate how Goffman's seminal contributions to microsociology may be fruitfully applied to Eastern societies.

Likewise Adam Kendon ("Goffman's approach to face-to-face interaction") and Anthony Giddens ("Goffman as a systematic social theorist") (both in Drew and Wootton, 1988) see Goffman as contributing to understandings of societal micro-processes beyond merely the Western case. After thoroughly investigating the myriad contexts within which face-toface interaction occurs - such as the modes of information routinely available to persons through simple co-presence; focused and unfocused interaction; and explicit interchanges and acts - Kendon concludes that Goffman's attention to the interplay of acts (and not necessarily to the individual actors themselves) provides a general framework which has the potential for informing comparative cross-cultural studies.

These works, and especially the above mentioned papers from Beyond 
Goffman, bring greater systematic understanding of human social interaction from within the analytical framework and terminology provided by Goffman.

\section{Systematizing Goffman: Frame analysis}

It seems the text of choice in reaching this newly systematized, crosscultural and multi-disciplinary understanding of social life is Goffman's Frame analysis (hereafter FA), as at least half of the articles in the two edited volumes feature the book prominently. Several merit comment.

Peter Manning's and Keith Hawkins' "Legal Decisions: A frame analytic perspective" (Riggins, 1990) successfully applies Goffman's ideas concerning how persons in everyday life "frame in" or "frame out" particular issues. This process is shown to be especially apposite with regard to how legal decisions are arrived at and even made meaningful in the first place (i.e., through primary frames). This work helps reaffirm Goffman's relevance to law and legal theory (also see Lyman, 1991: 202).

The idea of rules of relevance and irrelevance is also explored by P.M. Strong's "Minor courtesies and macro structures" (Drew and Wootton, 1988). Drawing from Goffman's "Fun in games," Strong shows that the service relationships specific to pediatric clinics (e.g., doctor-patient) have a unique array of interpersonal rituals embedded in the setting which provides patients with cues to meaning and interpretation. Arguing that Goffman often fell short of providing a "clear understanding of the interactional structure of the participants" (p. 158), Strong suggests that the ritual order of the clinic is, a product of larger social structural arrangements. Besides the purely situational, we must also be attentive to the sequential organization of ordinary conduct.

Christian Heath's "Embarrassment and interactional organization" (Drew and Wootton, 1988) arrives at nearly the same conclusion after observing episodes of embarrassment in a number of video-recorded doctor-patient interactions. Although the Strong and Heath critiques have merit, they are somewhat tiresome insofar as a nearly identical criticism of Goffman had already been launched twenty years ago by Garfinkel (see especially Garfinkel, 1967: 165-174).

George Park's "Making sense of religion by direct observation: An application of frame analysis" (Riggins, 1990), reworks Goffman's notion of "laminations" to forge a novel and convincing explanation of how religion coexists with the lay world. He suggests that religion evolves in terms of three supernatural frames: the proto-religious, the animistic, and the deistic. The inconsistencies which exist between these frames and the 
lay world are hidden within their respective laminations.

Perhaps the most interesting paper is Paul Bouissac's "Incidents, accidents, failures: The representation of negative experience in public entertainment" (Riggins, 1990). Bouissac extends Goffman's discussion of the "manufacture of negative experience" (chapter 11 of FA) by analyzing the ways in which circus acts - here specifically a clown and trapeze act challenge the generally unquestioned entertainment frame through the (sometimes purposeful) manufacture of negative experience. The three types of negative experience Bouissac elaborates - incidents, accidents, and failures - are part and parcel to the operation of commercial entertainment venues which, in order to ensure their own profitability and livelihood, are dedicated to enhancing the thrill of the audience.

This is all well and good, and the essay works within the author's semiotic framework. But perhaps Bouissac missed an opportunity to systematize, from within a more overtly sociological framework, Goffman's negative experience schema even further. To wit, the anticipation created in the audience from the mere threat that something might go wrong up on the trapeze, or the flustered and embarrassed "flooding out" of audience members reacting to George Carl's 15-minute frame-breaking comedy act - or rather "anti-performance," gloriously described in microdetail by Bouissac (Riggins, 1990: 417-420) - are virtually identical to the sort of affective states aroused within individuals seeking the type of "action" described by Goffman (1967) in "Where the action is." In keeping with Goffman's ongoing preoccupation with the dialectic of individual/society and performer/audience, "action" may be viewed as the participatory or performer aspect, and "negative experience" the nonparticipatory or audience aspect of this particular species of framed activity. ${ }^{6}$

Lastly, Richard L. Lanigan's "Is Erving Goffman a phenomenologist?" (Riggins, 1990) analyzes the place of phenomenology in Frame Analysis. Judged against Merleau-Ponty's three step phenomenological method of description, reduction, and interpretation, Lanigan finds that Goffman's method stays true only to the first step of the process, namely description. ${ }^{7}$ Agreeing in effect with Gonos (1977), Lanigan suggests that Goffman's structuralism keeps him from adopting the true phenomenological position. ${ }^{8}$ Because "method is not theory," regardless how "rhetorically appealing" his descriptions and taxonomy of the minutia of everyday life may be, Lanigan concludes that Goffman cannot rightly be considered a phenomenologist (Riggins, 1990: 106). ${ }^{9}$

The controversy whether and to what extent Goffman could be considered a phenomenologist attests to the remarkable array of interpretations available to students of his work (Vester, 1989: 191). For example, P.M. Strong (1983: 347) asks, "Is he primarily an anthropologist or a sociologist, 
a social psychologist or an ethologist, or is he perhaps really a student of linguistics?" Dean MacCannell (1983) makes the strong case that he is as much semiotician as he is sociologist. Richard Brown $(1977: 13,205)$ has even suggested that Goffman is a microfunctionalist. In the end, Paul Atkinson (1989:59) is probably right in suggesting that Goffman "defied categorization in relation to a particular school or tradition of sociological theory." 10

\section{Goffman, ethology and general theory}

Tom Burns (1992) realizes this as well, and his book is dedicated to retracing Goffman's disparate intellectual roots. His careful analysis helps disentangle the major intellectual influences on Goffman, these being Durkheim, Simmel, the Chicago School, linguistic philosophy and animal ethology.

The place of ethology in Goffman's writings has been an unpopular and generally overlooked topic among sociologists, so it is to his credit that Burns gives it some attention. "The important point is that, beginning with his earlier work with Gregory Bateson's group at Berkeley, ${ }^{12}$ Goffman preferred to observe how people behaved rather than listening to them talk about how they behaved. ${ }^{13}$ This "direct method" became especially conspicuous in such works as Behavior in public places and Relations in public, the mental approach and glossary of which appropriated in large part from students of animal behavior. What Goffman saw in public - the largely unthinking gestures, posturings, and other forms of verbal and nonverbal behavior (signs) which persons continually give off and receive while navigating their way through the teeming streets and alleys of the metropolis - lent itself admirably to the ethological frame. ${ }^{14}$

Furthermore, Burns (1992: 78) notes that much of Goffman's work during this period led him toward the general observation that however human beings conduct themselves in the presence of others, they do so always with an eye toward making some kind of "claim." Just as ethologists have observed a range of territorial behavior among animals, so too Goffman observed a range of "territorial claims" among humans. These include taking turns at talk; "markers" for staking claims to occupancy; "information preserves," or facts about oneself commonly thought to be private; and "conversation preserves," namely the right to decide or control who is allowed in and who is to be kept out of circles of current talk. In fact, three of Goffman's most important concepts - presentation, claims, and ritual - can be considered appropriations from the corresponding ethological concepts of display, territory, and to a lesser extent, ritualiza- 
tion.

I believe that Giddens is correct in claiming that Goffman was indeed engaged in systematic theory, and that we may think of him above all as the "theorist of co-presence" (Drew and Wootton, 1988: 255). ${ }^{15}$ Frame analysis provides a hint of Goffman's concern for general theory, as he states (1974: 5) that:

A game such as chess generates a habitable unive:se for those who can follow it, a plane of being, a cast of characters with a seemingly unlimited number of different situations and acts through which to realize their natures and destinies. Yet much of this is reducible to a small set of interdependent rules and practices.

In other words, beginning with a few very simple rules governing how each of the six pieces may move, chess is the sort of game that nevertheless provides a nearly infinite variety of possible endgames and conclusions. Goffman then goes on to suggest:

If the meaningfulness of everyday activity is similarly dependent on a closed, finite set of rules, then explication of them would give one a powerful means of analyzing social life.

In essence, Goffman went out into the empirical social world and observed the enormous variety of human activity residing there, within the interaction order, hoping some day to discover the "closed, finite set of rules" which might then provide a powerful means for analyzing social life. But as we know, Goffman never got around to putting forth such general propositions (although there have been a few attempts to axiomatize Goffman, such as Turner, 1991). Even close to his death, Goffman (1983: 17) complained that human social life was still but a "small scab on the face of nature, not particularly amenable to deep systematic analysis."

So Goffman had to resign himself to dutifully going about his primitive work of discovering and describing this new species, the unnoticed world of everyday interaction. As Collins has put it, much of Goffman's work thereby "looks like a microsociological Linneus, laying out classifications and modestly waiting for some later Darwin to bring these materials into an explanatory theory" (Drew and Wootton, 1988: 43).

The closest Goffman ever came in linking up his observations of the social world to some overarching law was to the work of ethologists and their discoveries of rules of territoriality regulating interaction among animals. This feature of Goffman's work is not recognized explicitly by any of the authors that I have discussed. That Goffman should rely so heavily on such an alien tradition of thought may deeply disturb many sociologists. One notices, as a consequence, that this particular aspect of Goffman's 
work is continually repressed in secondary analyses and discussions of his work.

On the other hand, I may be overstating my case here; after all, Goffman often warned against taking too seriously some of his more ethologicallytinged observations (see especially his disclaimers in Relations in public). But this authorial position is due as much as anything, I believe, to Goffman's intellectual eclecticism. Goffman's influences were multiple and even seemingly disparate, illustrated for example by his ability to deftly switch from Durkheimian notions of ritual to ritualization, as he did in Gender advertisements and Forms of talk. Besides Goffman's aversion to having his work pigeonholed (Strong, 1983), Robin Williams' "Understanding Goffman's methods" (Drew and Wootton, 1988) documents that Goffman rarely spoke of epistemology and method. As a consequence, Goffman was rarely in a position where he felt he had to defend his knowledge claims as per the sort of foundationalism attended to by those more overtly committed to general theory, such as Talcott Parsons. Goffman's interest in the rhetoric of talk is realized as a lived conviction in his own texts through the guise of the rhetoric of disavowal (Hazelrigg, 1992), a strategy calculated to underscore the tenuousness and "very serious limitations" of his findings.

\section{Conclusion: Some disciplinary concerns ${ }^{16}$}

The Drew and Wootton, Riggins, and Burns volumes represent the current state of the art in Goffman studies. Although they all contribute to the project of making greater sense of Goffman and illustrating the utility of his concepts for sociology, there is much work yet to be done. Perhaps the greatest challenge is to demonstrate how the thought of sociological masters such as Goffman might be more successfully applied to or linked up with neighboring disciplines which have arisen largely as a result of our own neglect, including women's studies, cultural studies, community studies, and ethnic studies (although the Riggins volume has made headway in some of these areas from a semiotic perspective). If a thinker as important as Goffman cannot be made relevant to other disciplines in the social sciences and humanities, much less even to our own, dominated as it is by quantitative methods (Posner, 1978), what does this say about the vitality of and future prospects for sociology?

That book still waits to be written. 


\section{Notes}

1. For a much fuller biographical account, see Winkin's (1988) extensive interview of Goffman.

2. Philip Manning's (1992) new monograph on Goffman arrived too late to be included in this review.

3. Although at an astonishing $\$ 145.00$, the purchase of this book will no doubt be limited to libraries and only the most diehard Goffman enthusiasts.

4. For reasons of space I will not be able to deal directly with Levinson's and Schegloff's somewhat longer papers, both of which are concerned with linguistic aspects of the interaction order. For a thorough discussion of these papers however, see Auer (1991).

5. In the Indian case, this amounts to the difference between the "mythic" text (Goffman, 1979) as embodied in the rules and proscriptions of the Hindu caste system, and the "performance text" representing the actual social practices of members of the varioust castes.

6. It is worth noting that Goffman (1967: 149) begins "Where the action is" with a quote: "To be on the wire is life; the rest is waiting" - which, as Goffman explains in a footnote, is attributed to the great Karl Wallenda on the occasion of his returning to the high wire after his troupe's fatal Detroit accident. Hence the action-negative experience link is complete.

7. This agrees somewhat with Lofland's (1980:33) conclusion that Goffman is involved not so much with theory per se but with description and taxonomy: "Goffman is not propounding full theory. Nonetheless, the step he does take is a necessary first step in developing theory. He may, in this sense, be making important contributions in the direction of theory."

8. Lanigan's (Riggins, 1990: 13) major evidence of Goffman's structuralism is this famous pronouncement from FA: "I personally hold society to be first in every way and any individual's current involvements to be second; this report deals only with matters that are second."

9. Lanigan's argument is reminiscent of the exchange between Denzin and Keller (1981) and Goffman (1981b) over the role of phenomenology and structuralism in FA's conceptual scheme. For a nice summary and appropriately pointed commentary on this issue, see MacCannell (1983).

10. The ambiguities in Goffman's intellectual lineage have led to the consideration of textual analysis as a possible method for resolving these disputes. The fragmented and multi-faceted nature of Goffman's influences has prompted Charles Battershill ("Erving Goffman as a precursor to post-modern sociology," in BG) to argue for the relevance of Goffman to contemporary efforts in textual analysis and postmodernism (see also Vester, 1989), and these support as well Patricia Clough's observations in her "Reading Goffman: Toward the deconstruction of sociology" (also in BG).

11. Some of the few that have dealt with Goffman and ethology are for example Erwin (1992), Callan (1970), Cheal (1988a), Vine (1975), Pages-Delon (1985), Bouissac's article from Beyond Goffman, and much of Adam Kendon's work. Although Goffman disliked having his work pinned down by any single affiliatory catch phrase, he nonetheless consented on at least one occasion to the "ad hoc weasel phrase "interaction ethology" (Sebeok, 1991: 32). For the most recent discussion of Goffman, ethology, and their contributions to the study of human social interaction, see Conein (1992). 
12. The suggestion (p. 13) that Goffman came to establish a "working relationship" with Gregory Bateson's group at the Palo Alto V.A. hospital in the 1950s is perhaps Burns's most contentious claim. For example, Yves Winkin states in personal correspondence that "He [Goffman] never was in contact - so far as I was able to find out through my interviews and some archival work in the Bateson archives at U.C. Santa Cruz - with the so-called 'Bateson group."” Since Burns provides no documentation for his claim, it is likely that Winkin is correct on this point.

13. For those who may doubt Burns on this point, consider the following corroboration from Goffman (1989: 131): "I don't give hardly any weight to what people say, but I try to triangulate what they're saying with events."

14. Ray Birdwhistell most certainly was a source for some of Goffman's more ethologically-tinged observations, as in the following: "Attention to personal appearance often entails some pleasurable self-stimulation, providing additional reason for appropriating the terms 'preening gesture' and 'grooming behavior' from animal sociology for use in describing human social behavior' (Goffman, 1963b: 67).

15. My thoughts on Goffman's relation to general theory are developed more fully in Chriss (1992).

16. I am grateful to Dean MacCannell for prompting me to think about Goffman in relation to these disciplinary issues.

\section{References}

Abrahams, Roger D. (1984). Goffman reconsidered: Pros and players. Raritan 3(4): 76-94.

Agger, B. (1989). Socio(onto)logy: A disciplinary reading. Champaign: University of Illinois Press.

Atkinson, P. (1989). Goffman's poetics. Human Studies 12: 59-76.

Auer, P. (1991). Review of Drew and Wootton (Eds.), Erving Goffman: Exploring the interaction order. Linguistics 29(1): 177-189.

Becker, Alton L. (1984). Goffman's animated language game. Raritan 3(4): 95-112.

Berger, B.M. (1973). A fan letter on Erving Goffman. Dissent 20: 353-361 .

Bock, P.K. (1988). The importance of Erving Goffman to psychological anthropology. Ethos 16(1): 3-20.

Brown, R.H. (1977). A poetic for sociology: Toward a logic of discovery for the human sciences. Cambridge: Cambridge University Press.

Brown, R.H. (1990). Rhetoric, textuality, and the postmodern turn in sociological theory. Sociological Theory 8(2): 188-197.

Burns, T. (1992). Erving Goffman. New York: Routledge.

Callan, H. (1970). Ethology and society: Toward an anthropological view. Oxford: Clarendon Press.

Cheal, D.J. (1988a). The postmodern origin of ritual. Journal for the Theory of Social Behaviour 8(3): 269-290.

Cheal, D.J. (1988b). Relationships in time: Ritual, social structure, and the life course. Studies in Symbolic Interaction 9: 83-109.

Chriss, J.J. (1992). The construction of general sociological theory: From Parsons to Goffman ... and beyond. Paper presented at the annual meeting of the 
American Sociological Association, Pittsburgh, PA, 23 August 1992.

Chriss, J.J. (1993). Durkheim's cult of the individual as civil religion: Its appropriation by Erving Goffman. Sociological Spectrum 13(2): 251-275.

Clough, P.T. (1992). The end(s) of ethnography: From realism to social criticism. Newbury Park: Sage.

Collins, R. (1975). Conflict sociology: Towards an explanatory science. New York: Academic Press.

Collins, R. (1980). Erving Goffman and the development of modern social theory. In J. Ditton, The view from Goffman, pp. 170-209. New York: St. Martin's Press.

Collins, R. (1986). The passing of intellectual generations: Reflections on the death of Erving Goffman. Sociological Theory 4: 106-113.

Collins, R. and Makowsky, M. (1972). The discovery of society. New York: Random House.

Conein, B. (1992). Ethologie et sociologie: Contribution de L'ethologie à la theorie de l'interaction sociale. Revue Française de Sociologie 33(1): 87-104.

Denzin, N.K. and Keller, C.M. (1981). Frame analysis reconsidered. Contemporary Sociology 10(1) 52-60.

Denzin, N.K. (1991). Representing lived experiences in ethnographic texts. Studies in Symbolic Interaction 12: 59-70. Press.

Drew, P. and Wootton, A. (1988). Erving Goffman: Exploring the interaction order. Cambridge: Polity.

Erwin, Robert (1992). The nature of Goffman. Centennial Review 36(2): 327-342.

Freidson, E. (1983). Celebrating Erving Goffman. Contemporary Sociology 12(4): 359-362.

Garfinkel, H. (1967). Studies in ethnomethodology. Englewood Cliffs, NJ: Prentice-Hall.

Goffman, E. (1953). Communication conduct in an island community. Ph.D. dissertation, University of Chicago.

Goffman, E. (1959). The presentation of self in everyday life. New York: AnchorDoubleday.

Goffman, E. (1961a). Asylums: Essays on the social situation of mental patients and other inmates. New York: Doubleday Anchor.

Goffman, E. (1961b). Fun in games. In Encounters: Two studies in the sociology of interaction, pp. 15-81. Indianapolis: Bobbs-Merrill.

Goffman, E. (1963a). Stigma: Notes on the management of spoiled identity. Englewood Cliffs, NJ: Prentice-Hall.

Goffman, E. (1963b). Behavior in public places: Notes on the social organization of gatherings. New York: Free Press.

Goffman, E. (1967). Where the action is. In Interaction ritual: Essays on face-toface behavior, pp. 149-270. New York: Pantheon.

Goffman, E. (1971). Relations in public: Microstudies of the public order. New York: Basic Books.

Goffman, E. (1974). Frame analysis: An essay on the organization of experience. Boston: Northeastern University Press.

Goffman, E. (1979). Gender advertisements. New York: Harper and Row.

Goffman, E. (1981a). Forms of talk. Philadelphia: University of Pennsylvania Press.

Goffman, E. (1981b). A reply to Denzin and Keller. Contemporary Sociology 10(1): $60-68$. 
Goffman, E. (1983). The interaction order. American Sociological Review 48: $1-17$.

Goffman, E. (1989). On fieldwork. Journal of Contemporary Ethnography 18(2): 123-132.

Gonos, G. (1977). "Situation" versus "frame": The "interactionist" and the "structuralist" analyses of everyday life. American Sociological Review 42: 854-867.

Gouldner, A.W. (1969). Personal reality, social theory, and the tragic dimension in science. In G. Boalt, The sociology of research, pp. xv-xxxviii. Carbondale: Southern Illinois University Press.

Hazelrigg, L. (1992). Reading Goffman's framing as provocation of a discipline. Human Studies 15(2-3): 239-264.

Hymes, D. (1984). On Erving Goffman. Theory and Society 13(5): 621-631.

Lofland, J. (1980). Early Goffman: Style, structure, substance, soul. In J. Ditton, The view from Goffman, pp. 24-51. New York: St. Martin's Press.

Lofland, J. (1984). Erving Goffman's sociological legacies. Urban Life 13(1): 7-34.

Lyman, S.M. (1991). Animal faith, puritanism, and the Schutz-Gurwitsch debate: A commentary. Human Studies 14(2-3): 199-206.

MacCannell, D. (1983). Erving Goffman (1922-1982). Semiotica 45(1/2): 1-33.

Manning, Philip (1992). Erving Goffman and modern sociology. Stanford: Stanford University Press.

Marx, G.T. (1984). Role models and role distance: A remembrance of Erving Goffman. Theory and Society 13(5): 649-662.

McGregor, G. (1986). A view from the fort: Erving Goffman as Canadian. Canadian Review of Sociology and Anthropology 4: 531-543.

Miller, D.L. (1982). Ritual in the work of Durkheim and Goffman: The link between the macro and the micro. Humanity and Society 6: 122-134.

Mitchell, J.N. (1978). Social exchange, dramaturgy and ethnomethodology: Toward a paradigmatic synthesis. New York: Elsevier.

Pages-Delon, M. (1985). Elements pour une typologie des situations sociales de mise en jeu de l'apparence corporelle. Revue de l'Institut de Sociologie, (3-4): 487-496.

Posner, J. (1978). Erving Goffman: His presentation of self. Philosophy of the Social Sciences 8: 67-78.

Rawls, A.W. (1987). The interaction order sui generis: Goffman's contribution to social theory. Sociological Theory 5(2): 136-149.

Riggins, S. (Ed.) (1990). Beyond Goffman: Studies on communication, institution, and social interaction. Berlin: Mouton de Gruyter.

Sebeok, T.A. (1991). American signatures: Semiotic inquiry and method. Norman, OK: University of Oklahoma Press.

Seidman, S. (1991). The end of sociological theory: The postmodern hope. Sociological Theory 9(2) 131-146.

Seidman, S. (1992). Postmodern social theory as narrative with a moral intent. In S. Seidman and D.G. Wagner (Eds.), Postmodernism and social theory, pp. 47-81. Cambridge: Blackwell.

Stein, M. (1991). Sociology and the prosaic. Sociological Inquiry 61(4): 421-433.

Strong, P.M. (1983). The importance of being Erving: Erving Goffman, 1922-1982. Sociology of Health and Illness 5(3): 345-355.

Travers, A. (1992). The conversion of self in everyday life. Human Studies 
15(2-3): 169-238.

Turner, J.H. (1989). Introduction: Can sociology be a cumulative science? In J.H. Turner (Ed.), Theory building in sociology, Pp. 8-18. Newbury Park, CA: Sage.

Turner, J.H. (1991). Dramaturgical theory: Erving Goffman. In J.H. Turner, The structure of sociological theory, 5th ed., pp. 447-471. Belmont, CA: Wadsworth.

Vester, H. (1989). Erving Goffman's sociology as a semiotics of postmodern culture. Semiotica 76(3/4): 191-203.

Vine, I. (1975). Territoriality and the spatial regulation of interaction. In A. Kendon, R.M. Harris and M.R. Key (Eds.), Organization of behavior in face-toface interaction, pp. 357-387. The Hague: Mouton.

Williams, R. (1983). Sociological tropes: A tribute to Erving Goffman. Theory, Culture and Society 2: 99-102.

Williams, S.J. (1986). Appraising Goffman. British Journal of Sociology 37(3): 348-369.

Winkin, Y. (1988). Erving Goffman: Portrait du sociologue en jeune homme. In Y. Winkin (Ed.), Erving Goffman: Les moments et leurs hommes, pp. 13-92. Paris: Editions Seuil.

Winkin, Y. (1991). Erving Goffman: Outline of an intellectual biography. Unpublished manuscript, Department of Landscape Architecture, University of Pennsylvania.

Wollheim, R. (1984). The thread of life. Cambridge: Harvard University Press. 